Doi: https://doi.org/10.31578/jebs.v6i2.235

\title{
Teachers' Views on Music Education Practices in Secondary Education in Distance Education During the COVID-19 Pandemic Process
}

\section{Gülnihal GÜL*}

\begin{abstract}
In this study, it was aimed to determine the views of music teachers who have worked in secondary education during the COVID19 Pandemic process regarding the music lessons conducted via distance education. The study group of the research consisted of 11 music teachers who were determined by convenience sampling method. The data were collected using a semi-structured interview consisting of 6 questions and a demographic information form. In line with the findings obtained from this study, it was determined that the music teachers participating in the research had difficulties in classroom management, parents' approaches, technological equipment, internet problems and students' motivation. Besides, it was determined that the teachers used different technological teaching materials in the course, the achievements in the curriculum were partially achieved and the course evaluation process could not be carried out effectively enough.
\end{abstract}

Key words: COVID-19, pandemic, distance education, secondary education, music education

\section{Introduction}

Education, which is thought to have a critical importance in the development of societies, is affected by the rapid developments in information technologies. These rapid developments supported the development of human resources and lifelong education understanding, and the idea of benefiting wider masses from the new opportunities offered by the digital age led to the spread of the distance education approach (Özbay, 2015; Parlak, 2017).

Distance education, in which different technologies can be incorporated and structured in the education process, regardless of time and place, is an effective form of learning where teachers and students are in different environments and a connection between student and educational resources is established (Yamamoto \& Altun, 2020; Can, 2020; Kılınç, 2015). Within the scope of the necessity of continuing education and training in a modern and innovative system following the requirements of the age, the understanding of distance learning has been included in the teaching process to use time, space, and existing resources efficiently.

In the world, it is seen that distance education practices started with "Steno Lessons" in Boston newspaper in 1728 for the first time, teaching with letter practices in 1843 and the first educational radio broadcast in the USA in 1920, and also since the 1940s television has been used for distance education (Arat \& Balkanlı, 2011). In Turkey, learning with letter practices first started

\footnotetext{
* Department of Music Education, Bursa Uludag University, Bursa, Turkey.
} Corresponding Email: gulnihal@uludag.edu.tr 
regarding foreign language training in 1953, distance education applications with the establishment of the Open University in Anadolu University in 1982 have become widespread (Arat \& Balkanlı, 2011; Eygü \& Karaman, 2013).

The first studies carried out for music education within the scope of distance education were the "Violin Teaching by Letter" methods prepared by Edip Günay and Ali Uçan (Canbay \& Nacakçı, 2011). Then, in 1975, it is seen that distance education application for the "Instrument Making and Repairing Knowledge" course for the Music Departments of Education Institutes were realized. Besides, the television music department founded by Hikmet Şimşek and the music education programs for children prepared by Muammer Sun for TRT is also considered within the scope of distance education applications (Canbay \& Nacakçı, 2011; Sakarya \& Zahal, 2020; Sağer, Eden \& Şallıel, 2014; Yungul, 2018).

Today, most of the distance education applications, which have features such as keeping the quality of existing educational resources, increasing the capacity of the education system, providing educational opportunities to the target audience (Göksel, 2015), are carried out at the higher education level (Özbay, 2015). However, with the COVID-19 epidemic that broke out in December 2019, an isolated life obligation was born all over the world including Turkey, and with this obligation, face-to-face activities in education were stopped, as in all areas, online work and products in these environments. It has become a necessity.

When the related literature is reviewed, it is stated that many national and international studies have been carried out on educational activities in the COVID-19 pandemic process. It is seen that there are studies on distance education on undergraduate level (Adnan \& Anwar, 2020; Buluk \& Eşitti, 2020; Daniel, 2020; Dikmen \& Bahçeci, 2020; Erkut, 2020; Genç \& Gümrükçüoğlu, 2020; Durak, Çankaya \&lizmirli, 2020; Karadağ \& Yücel, 2020; Paudel, 2021; Sandhu \& Wolf ,2020; Tartavulea et al., 2020) and at the general education level (Çakın \& Külekçi Akyavuz, 2020; Mengi \& Alpdoğan, 2020; Lee, Ward, Chang \& Downing, 2021; Basilaia \& Kvavadze, 2020). Besides, it has been determined that studies related to music education carried out during the pandemic process have taken place in the literature (Sağer, Özkişi, \& Yüceer, 2020; Sakarya \& Zahal, 2020; Baratè, Haus, \& Ludovico, 2020).

For an effective and efficient teaching process, It is of great importance that the teacher should design and develop the lesson well in order to determine or produce the teaching materials to be used in the course, to use these teaching materials effectively and efficiently in the process, and to make evaluations to determine whether the learning objectives have been achieved at the end of the process. In this context, the planning, development, and implementation of music education, which is thought to contribute to the social, psychological, cultural, educational, etc. development of the individual, is considered important in terms of positive contribution to the development of the individual's creative power, musical taste, analysis, and synthesis power. With this idea, this study aimed to determine the views of music teachers about the music lessons conducted via distance education in secondary schools during the COVID-19 pandemic process. For this purpose, the article sought answers to the following questions:

1. What are the views of the participants regarding the pedagogical competencies in the lessons conducted in distance education?

2. What are the views of the participants on the effectiveness of music lessons in distance education?

3. What are the views of the participants regarding the achievement of the outcomes in the curriculum with music education activities carried out in distance education?

4. What are the opinions of the participants regarding the use of technology-supported devices in the process of distance music education?

5. What are the opinions of the participants regarding the different applications in distance education? 
6. What are the opinions of the participants regarding the positive and negative effects of distance education in music education?

7.

\section{Method}

This section includes information about the research model, study group and obtaining data.

\subsection{Research model}

In the current study, one of the qualitative research methods, case study, was used. In a case study, a situation or event is examined in depth by focusing on 'how' and 'why' questions, in a certain time, using observation, interview, etc. (Gustafsson, 2017; Subaşı \& Okumuş, 2017). With this research based on a case study, teachers' views on secondary education practices in distance education in the COVID-19 pandemic process were tried to be determined by conducting in-depth interviews.

\subsection{Study group}

Convenience sampling was used to determine the study group. Convenience sampling is to determine an adequate amount of items among the available, fast, and easy-to-reach items (Baltacı, 2018; Patton, 2005). Interviews for the survey were conducted with 11 music teachers working in secondary schools in Turkey. Table 1 includes the findings of the demographic information of the participants.

Table 1. Demographic information of the participants

\begin{tabular}{|c|c|c|}
\hline Gender & $\mathbf{N}$ & $\%$ \\
\hline Female & 10 & 90.9 \\
\hline Male & 1 & 9.1 \\
\hline Total & 11 & 100 \\
\hline Age & $\mathbf{N}$ & $\%$ \\
\hline $24-30$ & 4 & 36.4 \\
\hline $31-37$ & 4 & 36.4 \\
\hline $45-51$ & 3 & 27.2 \\
\hline Total & 11 & 100 \\
\hline Service year duration & $\mathbf{N}$ & $\%$ \\
\hline $6-10$ years & 8 & 72.8 \\
\hline 20 years and above & 3 & 27.2 \\
\hline Total & 11 & 100 \\
\hline
\end{tabular}


As can be seen in Table 1, the majority (90.9\%) of the teachers participating in the study are female and $9.1 \%$ are male. $36.4 \%$ of the teachers were between the ages of $24-30,36.4 \%$ between the ages of $31-37$, and $27.2 \%$ between the ages of $45-51$; It has been determined that $72.8 \%$ of them have $6-10$ years of service, $27.2 \%$ of them have 20 years or more.

\subsection{Data collection tool}

The semi-structured interview technique, one of the types of interviews, was used to collect data on the research problem. In this technique, predetermined questions are asked to the participant. On the other hand, depending on the flow of the interview, the researcher can enable the person to carry the content of his / her answers in detail by asking additional questions according to the developing subject in addition to the pre-prepared questions (Adhabi \& Blash Anozie, 2017; Güler, Halıcıoğlu \& Taşğın, 2013; Özden \& Durdu, 2016). An interview consisting of 6 open-ended questions was developed by the researcher to obtain the research data. To ensure validity, these questions were asked to three field experts, and the questions were finalized for implementation in line with expert opinions.

\subsection{Collecting and analyzing data}

The descriptive analysis technique, one of the qualitative data methods, was used for analyzing the research data. In descriptive analysis, direct quotations from the interviewees are frequently used in line with the themes determined beforehand. The purpose of this type of analysis is to reveal what the collected data express about the research question and what results will be obtained (Dey, 1993; Yıldırım \& Şimşek, 2006).

The data obtained from the semi-structured interview results were coded, then divided into themes and interpreted. While making quotations, the names of the participants were shortened as participant 1 (K1), participant 2 (K2), etc. To ensure the reliability of the study, the data were presented to the opinion of two experts, and a consistency analysis was conducted. As a result of the research, consensus and differences of opinion were determined and the reliability calculation formula was calculated using $\mathrm{P}$ (Consistency Percentage) $=\mathrm{Na}$ (The number of items coded in the same form in two forms) * $100 / \mathrm{Nt}($ Total number of items in a form) (Çepni, 2005). The consistency between the evaluations of the experts was $86.6 \%$. Since this value is higher than $70 \%$, it is considered sufficient (Miles \& Huberman, 1994: cited in Baş, 2014), it is concluded that reliability is provided for data analysis.

\section{Findings and Results}

In this section, the findings obtained from the answers given to the research questions by the music teachers participating in the study are included.

In Table 2, sub-themes, codes, and sample views related to the "pedagogical competence theme" obtained from the participants' opinions regarding the pedagogical competencies of the participants in distance education lessons are given

Table 2. Participant views on their pedagogical competencies in distance education lessons

\begin{tabular}{|c|c|c|c|c|}
\hline Theme & Sub-theme & Codes & Participants & Sample Views \\
\hline 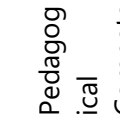 & & Classroom Management & $\begin{array}{l}\text { K2 ,K4, K8, } \\
\text { K10 }\end{array}$ & $\begin{array}{l}\text { Thanks to the application I use, I have the } \\
\text { opportunity to mute students' voices and images. } \\
\text { This makes my classroom management easier (P2). }\end{array}$ \\
\hline
\end{tabular}




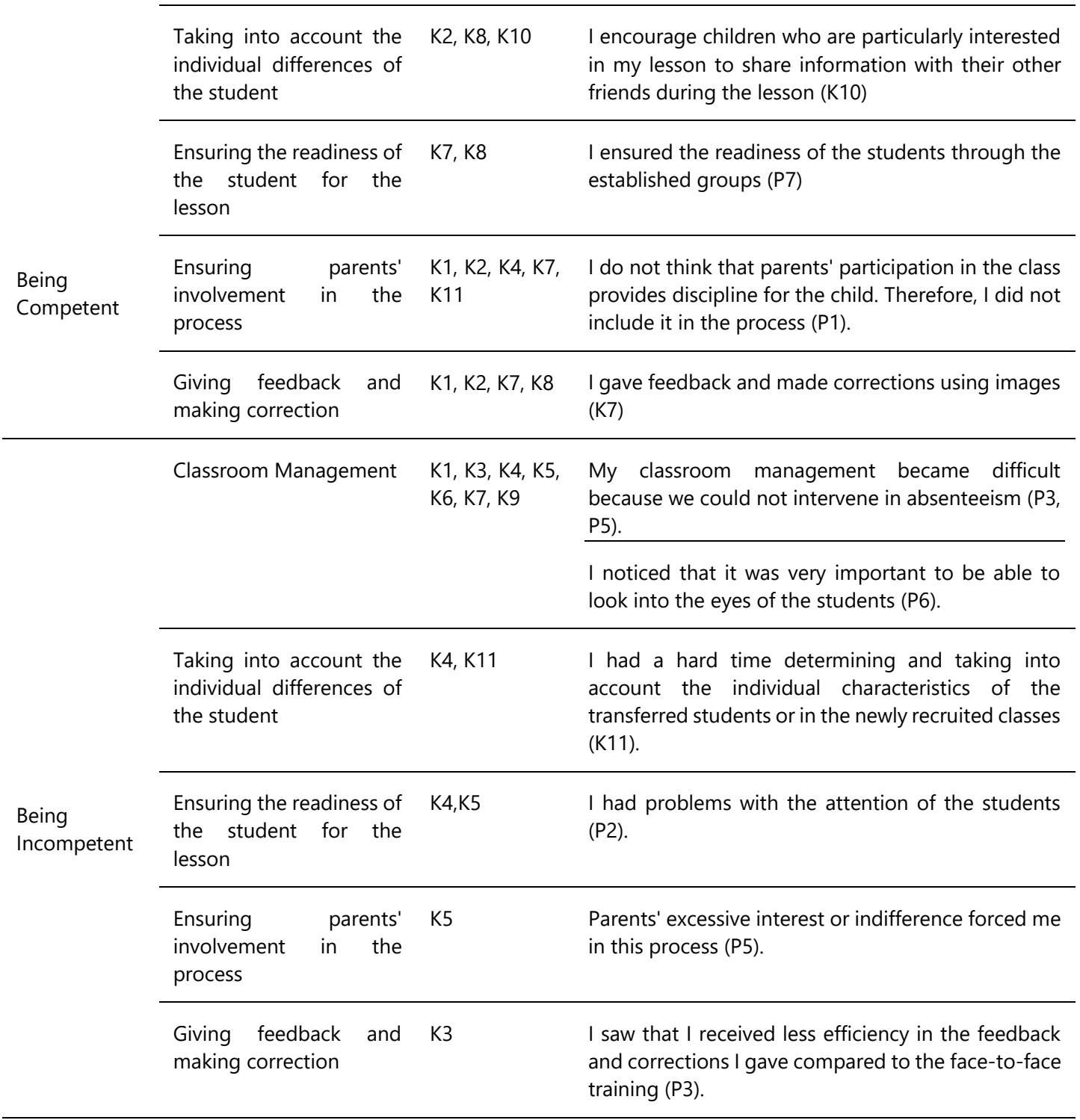

As it can be seen in Table 2, it was determined that the participants presented opinions regarding being pedagogically competent in the distance education process in the COVID-19 pandemic on classroom management (4), taking into account the individual differences of the students (3), ensuring the readiness of the student for the lesson (2) ensuring parents' involvement in the process (5) and giving feedback and making corrections; regarding being incompetent on classroom management (7) taking into account the individual differences of the students (2), ensuring the readiness of the student for the lesson (2), ensuring parents' involvement in the process (1), giving feedback and making corrections (1). Based on this, it can be said that teachers feel incompetent especially in classroom management in the distance education process.

In Table 3, sub-themes, codes, and sample expressions related to the "state of performing effective music education" theme obtained from the participants' views regarding the effectiveness of the music lesson that the participants perform in distance education are given. 
Table 3. Participant views on the state of performing effective music education in distance education

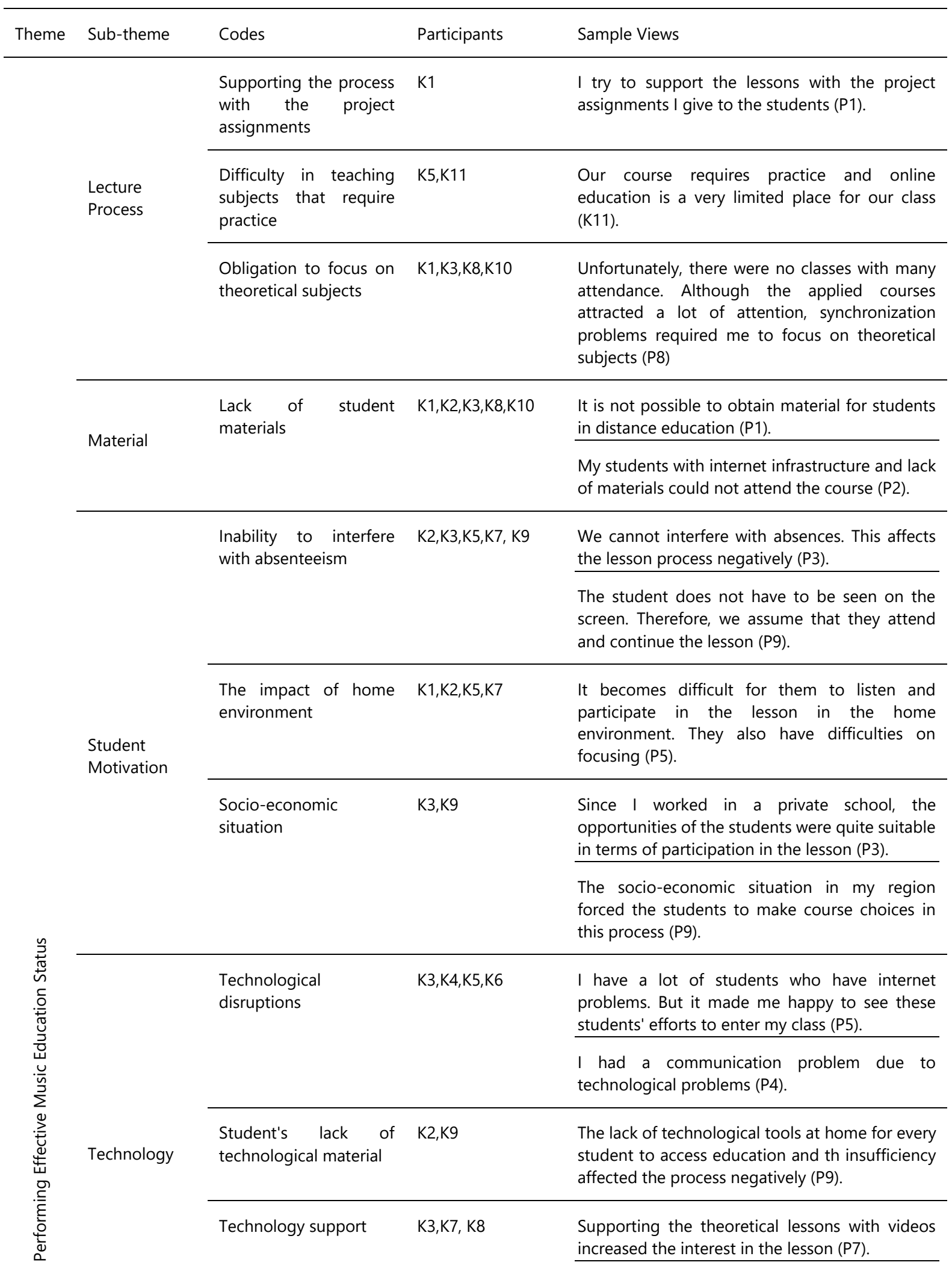


I saw that using programs that improve musical hearing positively affected class participation (P8).

As it can be seen in Table 3, the lecture process, material, student motivation, and technology affect the music education carried out in the distance education process during the COVID -19 pandemic process. It is observed that teachers have difficulties in teaching subjects that require practice in the lecture process (2) and have to focus on theoretical subjects (4). Also, it was determined that the students 'lack of material (5) also negatively affected the course process, Inability to interfere with absenteeism (5), attending classes in the home environment (4), and their socio-economic situations (2) were also found to be affecting student motivation. Besides, it is seen that the teachers think that the technological problems (4) and the technological material deficiencies of the students (2) also affect the process negatively.

In Table 4, sub-themes, codes, and sample expressions related to the "contribution to curriculum outcomes" theme obtained from the participant's views regarding the contribution of music education in distance education to the achievement of the curriculum outcomes are given.

Table 4. Participant views on the contribution of distance education to the state of achieving the curriculum outcomes of music education

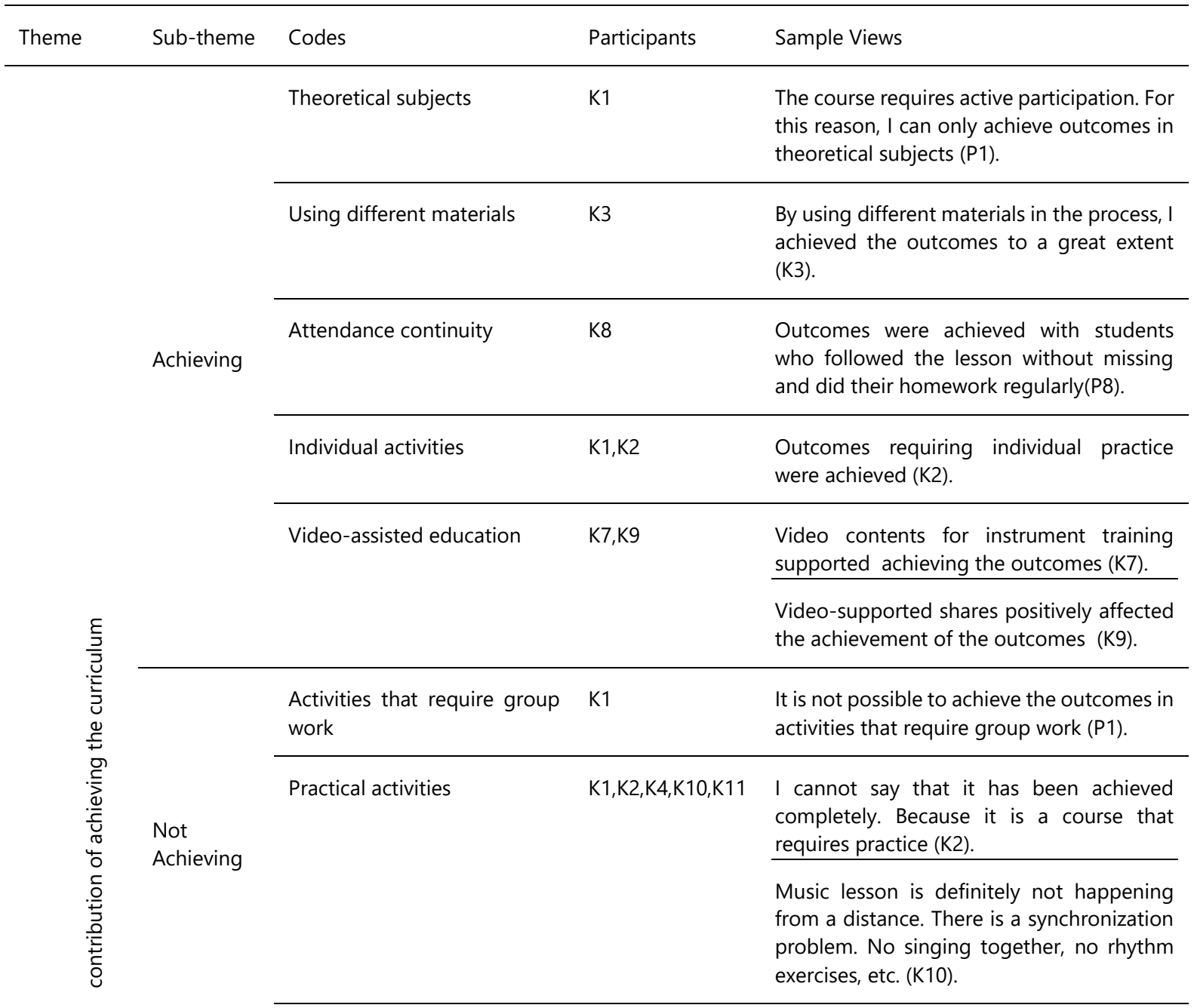




Student's lack of material K5 $\quad \begin{aligned} & \text { My students who could reach the materials } \\ & \text { in the activities were able to reach the } \\ & \text { outcomes (K5). }\end{aligned}$

Achievement of the Outcomes in the Curriculum: As seen in Table 3, there were participants who expressed their opinion regarding achieving the outcomes related to the theoretical subjects in the curriculum in the music education carried out with distance education during the COVID-19 pandemic process (1), and also the use of different materials and the continuity of the course (1) contributed achieving the outcomes. On the other hand, it is seen that there are participants who think that individual activities and video-supported education (2) contribute to the achievement of curriculum outcomes.

Not Achieving the Outcomes in the Curriculum: It is also seen that there are participants who gave their opinions about the situation of not achieving the outcomes in the curriculum with the distance music education performed in this process. It was determined that the participants stated that the outcomes related to the activities requiring group work in music lessons (1) and the outcomes related to the applied activities (5) were not reached. Besides, it is seen that there is one participant who stated that the lack of student material negatively affected the achievement of the outcomes.

In Table 5, codes and sample expressions related to the theme of "using technology supported tools" obtained from the participants' opinions regarding the use of technology-supported tools in distance music education are given.

Table 5.Participant views on the use of technology-supported tools in the distance music education process

\begin{tabular}{|c|c|c|c|}
\hline Theme & Codes & Participants & Sample Views \\
\hline & $\begin{array}{l}\text { EBA } \quad \text { Education } \\
\text { Information Network }\end{array}$ & $\mathrm{K} 5, \mathrm{~K} 6, \mathrm{~K} 7, \mathrm{~K} 8, \mathrm{~K} 9, \mathrm{~K} 10, \mathrm{~K} 11$ & $\begin{array}{l}\text { There were times when I used EBA, but it is } \\
\text { definitely insufficient (K5). }\end{array}$ \\
\hline & & & $\begin{array}{l}\text { I use. However, the content is too poor for the } \\
\text { music lesson }(K 7, K 8) \text {. }\end{array}$ \\
\hline & & & $\begin{array}{l}\text { Subject uploads related to the music lesson } \\
\text { have not been done in EBA (K10). }\end{array}$ \\
\hline & Powerpoint & $\mathrm{K} 1, \mathrm{~K} 2, \mathrm{~K} 3, \mathrm{~K} 8, \mathrm{~K} 10$ & $\begin{array}{l}\text { Since I could not always access healthy } \\
\text { materials on the subject in EBA, I mostly } \\
\text { benefited from Powerpoint presentations } \\
\text { (K10). }\end{array}$ \\
\hline & $\begin{array}{l}\text { Videos prepared by the } \\
\text { instructor }\end{array}$ & $\mathrm{K} 1, \mathrm{~K} 7$ & $\begin{array}{l}\text { I definitely prepare a Powerpoint presentation } \\
\text { in the course. In addition, I use individual } \\
\text { videos that I have prepared and Youtube } \\
\text { videos (K1). }\end{array}$ \\
\hline \multirow{3}{*}{ 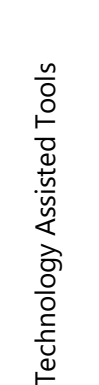 } & Youtube videos & $\mathrm{K} 1, \mathrm{~K} 7, \mathrm{~K} 8, \mathrm{~K} 10, \mathrm{~K} 11$ & $\begin{array}{l}\text { I have benefited Youtube videos suitable for } \\
\text { the subject (K11). }\end{array}$ \\
\hline & Whatsapp & $\mathrm{K} 2, \mathrm{~K} 4, \mathrm{~K} 6, \mathrm{~K} 7, \mathrm{~K} 8, \mathrm{~K} 10$ & $\begin{array}{l}\text { I shared the content of the course with the } \\
\text { students via Whatsapp (P4). } \\
\text { We always communicated with the children } \\
\text { via Whatsapp (K6). }\end{array}$ \\
\hline & & & $\begin{array}{l}\text { I used Whapsapp very effectively in my } \\
\text { lessons (K8). }\end{array}$ \\
\hline
\end{tabular}




\begin{tabular}{lll}
\hline Zoom & $\mathrm{K} 3, \mathrm{~K} 7, \mathrm{~K} 9$ & $\begin{array}{l}\text { I did music concerts from zoom. I did mini- } \\
\text { concerts with my enthusiastic students (K7). }\end{array}$ \\
\hline Documentaries & $\mathrm{K} 6$ & I have benefited from documentaries (K6). \\
\hline Instagram & $\mathrm{K} 6$ & I have benefited the events on Instagram. \\
\hline Ear training programs & $\mathrm{K} 8$ & $\begin{array}{l}\text { I used ear training programs to improve the } \\
\text { hearing ability of children (K8). }\end{array}$
\end{tabular}

As can be seen in Table 5, the participants benefited from technology-supported tools in the distance education process. The participants expressed their opinion in the direction of using EBA (Education Information Network) (7), Powerpoint (5), videos prepared by the instructor (2), Youtube videos (5), Whatsapp (6), Zoom (3), documentaries, Instagram, and ear programs (1). However, it is seen that the majority of the participants (7) used EBA but did not find the EBA content sufficient for music lessons. Table 6 includes sub-themes and codes related to the theme of "different practices" and sample expressions obtained from the participants' views on different practices in distance education during the COVID-19 pandemic process.

Table 6. Participant views on different practices in distance education

\begin{tabular}{|c|c|c|c|c|}
\hline Theme & Sub-theme & Codes & Participants & Sample Views \\
\hline & \multirow{6}{*}{ Achieving } & Material design works & $\mathrm{K} 1$ & $\begin{array}{l}\text { I made material designs made from } \\
\text { the materials in the house (K1). }\end{array}$ \\
\hline & & Individual activities & $\mathrm{K} 1, \mathrm{~K} 4, \mathrm{~K} 11$ & $\begin{array}{l}\text { I made all the activities individually } \\
\text { that need to be done collectively } \\
\text { (P4). }\end{array}$ \\
\hline & & Theoretical trivia games & $\mathrm{K} 1$ & $\begin{array}{l}\text { I often played theoretical trivia } \\
\text { games }(\mathrm{P} 1) \text {. }\end{array}$ \\
\hline & & Visual supported activities & K7 & $\begin{array}{l}\text { I have benefited from a lot of visual } \\
\text { activities (K7). }\end{array}$ \\
\hline & & Using technology assisted tools & $\mathrm{K} 7, \mathrm{~K} 8, \mathrm{~K} 10, \mathrm{~K} 11$ & $\begin{array}{l}\text { I explained the subjects by playing } \\
\text { with the students using } \\
\text { technological applications (P8). }\end{array}$ \\
\hline \multirow[b]{2}{*}{ 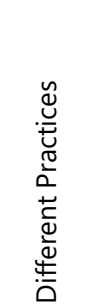 } & & $\begin{array}{l}\text { Rhythm exercises with materials } \\
\text { in the home environment }\end{array}$ & K9 & $\begin{array}{l}\text { I had rhythm exercises done with the } \\
\text { materials in their home (K9). }\end{array}$ \\
\hline & Not achieving & $\begin{array}{l}\text { Technological inadequacy of the } \\
\text { instructor }\end{array}$ & K2 & $\begin{array}{l}\text { I am not very familiar with the issues } \\
\text { related to music technology. I did } \\
\text { not have different practices than } \\
\text { what I did in face-to-face training } \\
\text { (P2). }\end{array}$ \\
\hline
\end{tabular}

As it can be seen in Table 6, the lecturers support the music education process with different practices in the distance education process. It was seen that lecturers shared views regarding material design (1), individual activities (3), theoretical trivia games (1), visual supported activities (1), using technology assisted tools (4), rhythm exercises with materials that students can easily find and use at home (1). However, it was determined that one participant could not perform different practices due to his/her technological inadequacy. 
In Table 7, sub-themes, codes, and sample expressions obtained from the views of the participants regarding the positive and negative effects of music education in distance education are given.

Table 7. Participant views on the positive and negative effects of distance education in music education

\begin{tabular}{|c|c|c|c|c|}
\hline Theme & Sub-theme & Codes & Participants & Sample Views \\
\hline \multirow{4}{*}{ 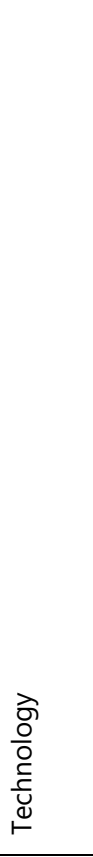 } & Positive & $\begin{array}{l}\text { Student's compatibility with } \\
\text { technology }\end{array}$ & $\mathrm{K} 1, \mathrm{~K} 3, \mathrm{~K} 4, \mathrm{~K} 5, \mathrm{~K} 7, \mathrm{~K} 8$ & $\begin{array}{l}\text { The students adapted to } \\
\text { this situation very quickly } \\
\text { (P5). } \\
\text { My students actively used } \\
\text { technology for music } \\
\text { lessons (P7). }\end{array}$ \\
\hline & \multirow[t]{3}{*}{ Negative } & Sound quality & $\mathrm{K} 1, \mathrm{~K} 3, \mathrm{~K} 5, \mathrm{~K} 6, \mathrm{~K} 11$ & $\begin{array}{l}\text { Sound quality made the } \\
\text { lesson sometimes } \\
\text { impossible (K11). }\end{array}$ \\
\hline & & Synchronization & $\mathrm{K} 1, \mathrm{~K} 2, \mathrm{~K} 3, \mathrm{~K} 8$ & $\begin{array}{l}\text { The biggest problem in the } \\
\text { music class was that the } \\
\text { voice did not go to } \\
\text { everyone at the same time. } \\
\text { It is not possible for them } \\
\text { to accompany live flute } \\
\text { work with words at the } \\
\text { same time (P1). }\end{array}$ \\
\hline & & Connection lost & $\mathrm{K} 5, \mathrm{~K} 6$ & $\begin{array}{l}\text { Disconnections have } \\
\text { always been a problem } \\
\text { (P6). }\end{array}$ \\
\hline \multirow[b]{5}{*}{ 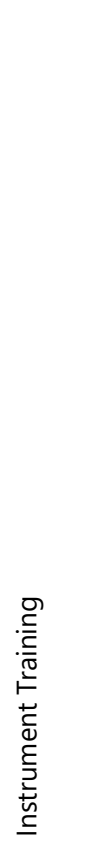 } & \multirow[t]{2}{*}{ Positive } & Supporting individual studies & K4 & $\begin{array}{l}\text { Since we could not do } \\
\text { collective works, I focused } \\
\text { on individual instrument } \\
\text { studies (P4). }\end{array}$ \\
\hline & & Developing Solfeggio Skills & K8 & $\begin{array}{l}\text { Note reading exercises } \\
\text { could be done (K8). }\end{array}$ \\
\hline & \multirow[t]{3}{*}{ Negative } & Lack of student material & $\mathrm{K} 1, \mathrm{~K} 8, \mathrm{~K} 9$ & $\begin{array}{l}\text { I had students who did not } \\
\text { have materials at home } \\
\text { due to their economic } \\
\text { problems (P9). }\end{array}$ \\
\hline & & Parents' negative approach & K2 & $\begin{array}{l}\text { They stated that the } \\
\text { parents were disturbed by } \\
\text { the noise at home while } \\
\text { the children were in the } \\
\text { music lesson ( } \mathrm{P} 2) \text {. }\end{array}$ \\
\hline & & $\begin{array}{l}\text { Inability to intervene in a timely } \\
\text { manner }\end{array}$ & $\mathrm{K} 7, \mathrm{~K} 9$ & $\begin{array}{l}\text { I could not intervene in } \\
\text { time by touching the } \\
\text { student, which negatively } \\
\text { affected the instrument } \\
\text { education ( } P 9 \text { ). }\end{array}$ \\
\hline \multirow{2}{*}{ 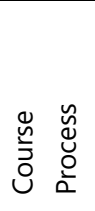 } & \multirow[t]{2}{*}{ Positive } & $\begin{array}{l}\text { Support for general culture } \\
\text { development }\end{array}$ & K10 & $\begin{array}{l}\text { In the lessons, information } \\
\text { about general culture was } \\
\text { mostly given (K10). }\end{array}$ \\
\hline & & $\begin{array}{l}\text { Contribution to the development } \\
\text { of students' sense of responsibility }\end{array}$ & K5 & $\begin{array}{l}\text { I saw the efforts of my } \\
\text { students in this difficult }\end{array}$ \\
\hline
\end{tabular}




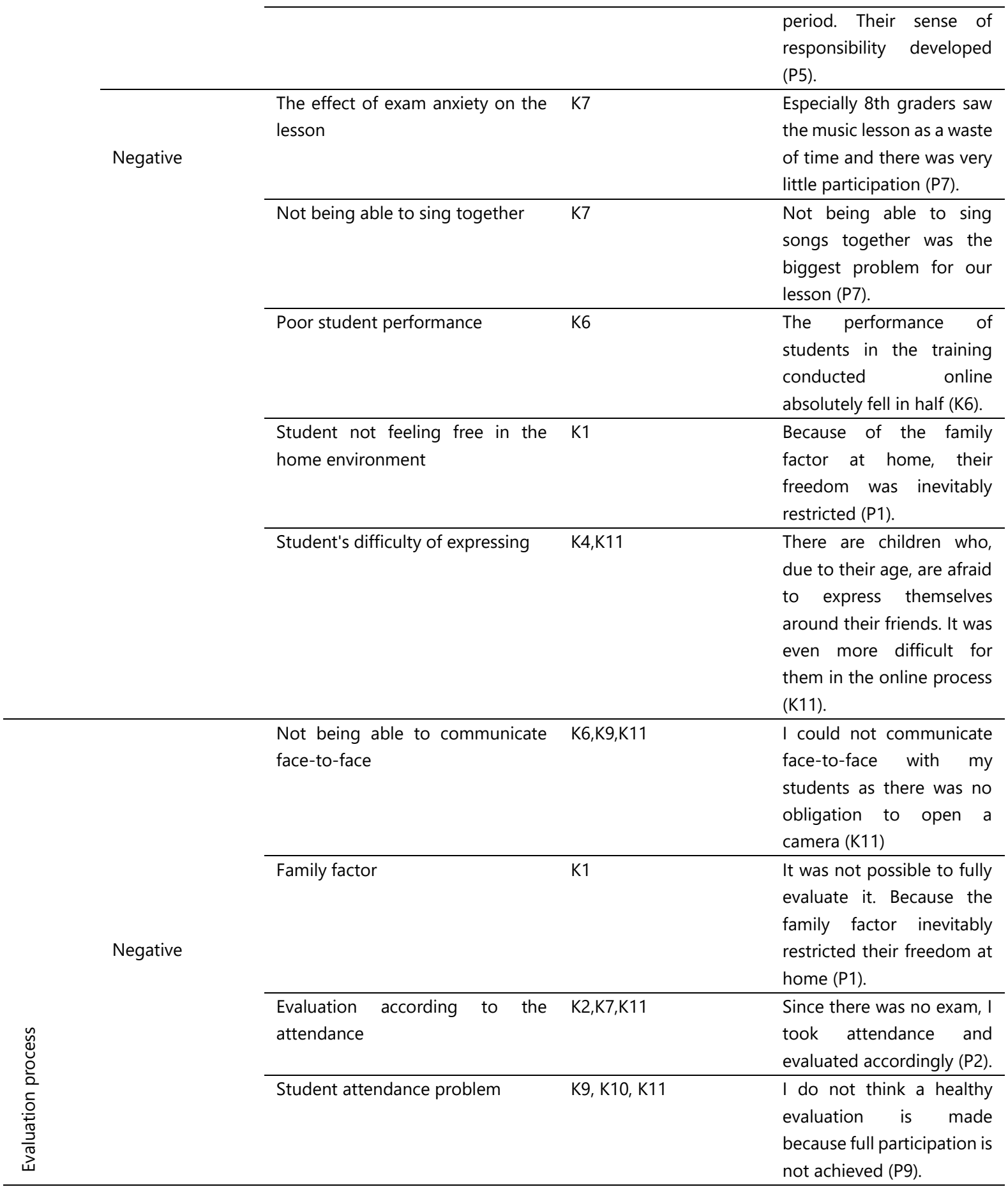

As it can be seen in Table 7, it has been determined that the participants in the music education carried out during the COVID-19 pandemic process have positive and negative reflections in terms of technology, instrument training, course process and evaluation process. It was concluded that the teachers easily adapted to technology (6) but experienced problems in online lessons in terms of sound quality (5), synchronization (4), and internet interruption (2). Since collective work cannot be done in instrument training, individual studies are supported (1) and note reading studies can be done (1); It was determined that the instrument training process was disrupted due to lack of student material (3), negative parent approach (1) and synchronization problems (2). However, the distance education process supports the general cultural development of the students (1) and contributes to 
the sense of responsibility (1); It has been determined that the difficulty of the students to express themselves (2), exam anxiety, not feeling free in the home environment and not being able to sing together (1) affect the lesson process negatively. Besides, it is observed that a healthy evaluation process in distance education was not carried out.

\section{Discussion}

In line with the findings obtained from this study, it was concluded that the music instructors participating in the study had difficulties, especially in classroom management during the distance education process. This situation is thought to arise because teachers have difficulties in using technological tools effectively. It is known that web-based technologies are tools that support the education process in today's technology age (Ekici, İnel Ekici, \& Altunışık, 2015). Therefore, effective use of these technologies by teachers is considered necessary in terms of supporting the educational process.

Researches show that parent support is important for a successful education process (Tümen Akyıldız, 2020; Roth, 2008). In the current study, it was determined that students do not feel comfortable due to their parents' negative attitudes, hence, they do not participate actively in music activities held in the home environment. Besides, it is among the results of the research that excessive parental attention also affects the process negatively. These findings reveal that balanced parent support is necessary for an effective and productive distance education process.

Research results show that students' adaptation to technology affects the course process positively. However, it is seen that technological devices and internet problems are frequently encountered problems, and the ministry has partially taken measures to overcome the problems regarding students' technological equipment. Different studies support the results of the research, showing that technological deficiencies affect the distance education process (Tümen Akyıldız, 2020). These technological problems that emerged during the COVID-19 pandemic process are thought to significantly affect the educational process. It has been determined that these technological problems are not only related to infrastructure, but also caused by socioeconomic differences among students.

According to the results obtained from the research findings, it is seen that all articipants used different technological tools in the process because the materials in EBA are not sufficient for music education. Several studies also revealed that different technological tools are used by teachers in distance education (Alsaleem, 2014; Tümen Akyıldız, 2020; Aksoy, Güçlü, \& Nayır, 2020). These results reveal that using different teaching technologies that support the teaching process in distance education together is necessary to maintain the student's interest in the lesson and to realize more effective and permanent learning.

Researches show that there may be low motivation in distance education lessons (Kuloğlu, 2020). Likewise, in the current study, it was determined that there has been mostly low motivation in students and partly in teachers during the distance education process. It was concluded that this low motivation of the students was caused by the fact that the lessons took place in the home environment and due to the teachers' inability to intervene in absenteeism. This situation negatively affected the learning process. Karaca, Topal, and Aldır (2011) state that a well-organized administrative structure and support services should be provided to students in distance education so that they do not break away from the lessons and participate actively. With this thought, in line with the findings obtained from the current research, it can be said that it is important for both teachers and students to work with administrations that plan the process well, support it and offer solutions to problems. 


\section{Conclusions and recommendations}

In the research, it was determined that the outcomes in the curriculum were partially achieved in the distance education process. It was determined that this situation was caused by the inadequacy of educational materials, as well as not being able to perform group activities and activities requiring implementation in online courses. On the other hand, it can be said that since group activities and activities requiring practice cannot be done in online lessons, the emphasis has been on individual work with students, and this situation has contributed to the development of the student's solfege skills and individual musical skills.

In the study, it was concluded that not being able to communicate face-to-face with the students because they do not have to open the camera, the students not being obliged to attend the class, and making attending the course an evaluation criteria negatively affected the evaluation process.

In the light of the findings obtained from the research results, the following recommendations can be made.

There are studies showing that in individual practices conducted in distance music education, student development is at a similar level to face-to-face education (Okan \& Arapgirli, 2018; Karahan, 2016; Orman \& Whitaker, 2010). However, it is thought that it will not be possible to fully achieve the behaviors that are expected to be gained by the student distance music education which is performed synchronously in general education, with the community and synchronization due to experiencing synchronization problems; It is deemed necessary to use distance education applications for supporting face-to-face education applications. With this in mind, it is deemed necessary for teachers to include synchronous and asynchronous distance education practices in face-to-face education practices, using them in areas such as assigning homework, participating in extracurricular activities, giving feedback to students, etc. that support students' knowledge and skills.

It is seen that teachers being technologically equipped has a positive impact on classroom management and achieving the targeted outcomes in the course in distance education. The fact that online applications were not used extensively in the field of education before the pandemic and some teachers were not informed about the applications they could use on the online platform caused problems in applications, especially at the beginning of distance education during the COVID-19 pandemic. For this reason, teachers should have the competence to use today's technologies in their lessons. To achieve this competence, it is deemed necessary to support them with in-service programs that contribute to their professional gains. Besides, it is recommended to include courses that pre-service teachers can use current technology effectively for their fields during their undergraduate education and offer them application opportunities where they can use instructional technologies that support their professional acquisitions.

It is of great importance that individuals, who will shape the future of societies, fairly benefit from the country's resources. In today's world, when the idea that especially the dissemination of distance education practices will contribute to the elimination of inequality of opportunity in education, the opportunity to benefit from formal education should not be taken away from children due to the lack of infrastructure and materials. For this reason, it is deemed necessary to provide these conditions with state support to all children who cannot access the infrastructure and materials to be used in line with the requirements of today's distance education due to their economic inadequacy. 


\section{References}

Adhabi, E.\& Blash Anozie . (2017). Literature review for the type of interview in qualitative research. International Jornal of Education, 9(3), 1-12. https://doi.org/10.5296/ije.v9i3.11483

Adnan, M. \& Anwar, K. (2020). Online learning amid the COVID-19 pandemic: Students' perspectives. Journal of Pedagogical Sociology and Psychology, 2(1), 45-51. https://doi.org/10.33902/JPSP

Aksoy, Y., Güçlü, O., \& Nayir, A.E. (2020). Özel müzik kurslarının pandemi sürecindeki uzaktan eğitim durumları [Distance education status of private music courses during the pandemic process]. Milli Eğitim, 49(1), 947-967.

Alsaleem, B. I. A. (2014). The effect of "WhatsApp" electronic dialogue journaling on improving writing vocabulary word choice and voice of EFL undergraduate Saudi Students. Harvard: 21st Century Academic Forum Conference Proceedings. http://www.21caf.org/uploads/1/3/5/2/13527682/alsaleem-hrd-conference_proceedings.pdf

Arat, T. \& Bakan, Ö. (2011). Uzaktan eğitim ve uygulamaları [Distance education and applications]. Selçuk Üniversitesi Sosyal Bilimler Meslek Yüksek Okulu Dergisi, 14(1-2), 363-374.

Baltacı, A. (2018). Nitel araştırmalarda örnekleme yöntemleri ve örnek hacmi sorunsalı üzerine kavramsal bir inceleme[A Conceptual Review of Sampling Methods and Sample Size Problems in Qualitative Research], Bitlis Eren Üniversitesi Sosyal Bilimler Enstitüsü Dergisi, 7 (1). 231-274.

Basilaia, G. \& Kvavadze, D. (2020). Transition to online education in schools during a SARS-CoV-2 coronavirus (COVID-19) pandemic in Georgia. Pedagogical Research, 5(4), 1-9. https://doi.org/10.29333/pr/7937

Baş, G. (2014). Lise öğrencilerinde yabancı dil öğrenme kaygısı: Nitel bir araştırma [Foreign language anxiety in high school students: A qualitative study]. Pamukkale Üniversitesi Eğitim Fakültesi Dergisi, 36, 101 - 119.

A. Baratè, Haus, G., \& Ludovic, L.A.. (2020). Learning, teaching, and making music together in the COVID-19 era through IEEE 1599, Paper presented at the 2020 International Conference on Software, Telecommunications and Computer Networks (SoftCOM), p.1-5. Doi: 10.23919/SoftCOM50211.2020.9238238.

Buluk, B. \& Eşitti, B. (2020). Koronavirüs (COVID-19) Sürecinde Uzaktan Eğitimin Turizm Lisans Öğrencileri Tarafından Değerlendirilmesi [Evaluation of distance learning by tourism undergraduate students in the process of coronavirus (COVID-19)], Journal of Awareness, 5(3), 285-298. https://doi.org/10.26809/joa.5.021

Can, E. (2020). Coronavirüs (COVID-19) pandemisi ve pedagojik yansımaları: Türkiye'de açık ve uzaktan eğitim uygulamaları [Coronavirus (COVID-19) pandemic and pedagogical implications: open and distance education applications in Turkey] . AUAd, 6(2), 11-53.

Canbay, A., \& Nacakçı, Z. (2011). Mektupla keman öğretim uygulamasına yönelik içerik analizi [Content analysis of application of teaching violin with letters]. Mehmet Akif Ersoy Üniversitesi Eğitim Fakültesi Dergisi, 1(21), 134-152.

Çakın, M.,\& Külekçi Akyavuz , E. (2020). COVID-19 süreci ve eğitime yansıması: öğretmen görüşlerinin incelenmesi [COVID-19 process and its reflections on education: An analysis on teacher' opinions]. International Journal of Social Sciences and Education Research, 6(2), 165-186.

Çepni, S. (2005). Araştırma ve proje çalışmalarına giriş [Introduction to research and project studies] (8. Baskı). Trabzon: Celepler Matbaacılık Yayın ve Dağıtım. 
Daniel, S.J. (2020). Education and the COVID-19 pandemic. Prospects, 49, 91-96.

Dey, I. (1993). Qualitative Data Analysis: A User-Friendly Guide for Social Scientists. London: Routledge Publications.

Dikmen., S. \& Bahçeci, F. (2020). COVID-19 Pandemisi Sürecinde Yükseköğretim Kurumlarının Uzaktan Eğitime Yönelik Stratejileri: Fırat Üniversitesi Örneği [Strategies of higher education institutions for distance education in the COVID-19 pandemic process: example of Fırat University], Fırat Üniversitesi Eğitim Bilimleri Enstitüsü Dergisi, 7(2), 78-98.

Durak, G., Çankaya, S., \& İzmirli, S. (2020). COVID-19 pandemi döneminde Türkiye'deki üniversitelerin uzaktan eğitim sistemlerinin incelenmesi [Examining the Turkish Universities' Distance Education Systems During the COVID-19 Pandemic]. Necatibey Eğitim Fakültesi Elektronik Fen ve Matematik Eğitimi Dergisi (EFMED), 14(1), 787-809. http://doi.org/10.17522/balikesirnef.743080

Ekici, M., İnel Ekici., \& Altunışık, S. (2015). Öğretmen adaylarinin web pedagojik içerik bilgisi öz-yeterlik algidüzeylerininçeşitli değişkenler açisindan incelenmesi [Investigation of pre-service teachers' web pedagogical content knowledge selfefficacy perceptions according to various variables]. Uluslararası Sosyal Araştırmalar Dergisi, 8(41), 960-967.

Erkut, E. (2020). COVID-19 sonrası yükseköğretim [Higher Education after COVID-19]. Yükseköğretim Dergisi, 10(2), 125-133. http://doi.org/10.2399/yod.20.002

Eygü, H., \& Karaman,S. (2013). Uzaktan eğitim öğrencilerinin memnuniyet algıları üzerine bir araştırma [A study on the satisfaction perceptions of the distance education students]. Kırıkale Üniversitesi Sosyal Bilimler Dergisi, 3(1), 36-59.

Genç, M.F. \& Gümrükçüoğlu, S. (2020). Koronavirüs (COVID-19) sürecinde ilâhiyat fakültesi öğrencilerinin uzaktan eğitime bakışları [The views of theology faculty students on distance education in the Coronavirus (COVID-19) process]. Turkish Studies, 15(4), 403-422. https://dx.doi.org/10.7827/TurkishStudies.43798

Göksel, N. (2015, 15 Ocak). Uzaktan eğitim: çevrimiçi öğrenmede sistem yaklaşımı [Distance education: systems approach to online learning] [Book launches Distance education: a systems view of online learning by M. Moore \& G. Kearsley]. AUAd, 1(1), 129-138.

Güler, A., Halıcıoğlu, B., \& Taşğın, S. (2013). Sosyal bilimlerde nitel araştırma[Qualitative research in social sciences]. Ankara: Seçkin Yayıncilık.

Gustafsson, J. (2017). Single case studies vs multiple case studies: a comparative study., Retrieved from www.divaportal.org/smash/get/diva2:1064378/FULLTEXT01.pdf

Karaca, O., Topal, M.,\& Aldır, Z. (2011, Aralık). Uzaktan eğitim sorunları [Distance education problems]. International Science and Technology Conference. Istanbul. Doi: 10.13140/2.1.2655.5680

Karadağ, E. \& Yücel, C. (2020). Yeni tip Koronavirüs pandemisi döneminde üniversitelerde uzaktan eğitim: Lisans öğrencileri kapsamında bir değerlendirme çalışması [Distance education at universities during the novel coronavirus pandemic: An analysis of undergraduate students' perceptions]. Yüksekögretim Dergisi, 10(2), 181-192. http://doi.org/10.2399/yod.20.730688

Karahan, A.S. (2016). Eş Zamanlı Uzaktan Piyano Öğretiminin Geleneksel Piyano Öğretimiyle Karşılaştırılması [The evaluation of synchronic distance piano teaching in comprasion with the traditional piano teaching], Turkish Studies, 11(21), 211- 228. 
Kılınç, M. (2015). Uzaktan eğitim uygulamalarının etkililiği üzerine bir araştırma "Inönü Üniversitesi uzaktan eğitim merkezi ilahiyat lisans tamamlama programı örneği" [A research on the effectiveness of distance education applications "Inönü University distance education center theology undergraduate completion program example"]. (Yayımlanmamış doktora tezi). İnönü Üniversitesi Eğitim Bilimleri Enstitüsü, Malatya.

Kuloğlu, M. (2020). Uzaktan Eğitimde Öğrencilerin Can Sıkıntısıyla Başa Çıkma Stratejileri [Students' boredom coping strategies in distance education]. Eğitim ve Teknoloji, 2(1) 48-63.

Lee, J.S., Ward, P.K., Chang, D.O.,\& Downing, M.K.(2021). Parenting activities and the transition to home-based education during the COVID-19 pandemic. Children and Youth Services Review, 122. https://doi.org/10.1016/j.childyouth.2020.105585

Mengi, A. \& Alpdoğan, Y. ( 2020). Covit-19 salgını sürecinde özel eğitim öğrencilerinin uzaktan eğitim süreçlerine ilişkin öğretmen görüşlerinin incelenmesi [Investigation of teacher's opininons about distance educatıon processes of students who receive special education during the Covit-19 pandemic period]. Milli Eğitim, 49(1),413-437. http://doi.org/10.37669/milliegitim.776226

Okan, S. \& Arapgirli, H. (2018). The effect of distance learning model on beginners' level violin instruction. Turkish Online Journal Of Distance Education, 20(1), 1-16.

Orman, K.E. \& Whitaker, A.. J. (2010). Time usage during face-to-face and synchronous distance music lessons. The American Journal of Distance Education, 24 (2), 92-103.

Özbay, Ö. (2015). Dünyada ve Türkiye'de uzaktan eğitimin güncel durumu[The current status of distance education ın the world and Turkey]. The Journal of International Educational Sciences, 2(5), 376-394. Doi: 10.16991/INESJOURNAL.174

Özden, M.Y., \& Durdu, L. (2016). Eğitimde üretim tabanlı çalışmalar için nitel araştırma yöntemleri [Qualitative research methods for production-based studies in education]. Ankara: Anı Yayıncılık.

Parlak, B. (2017). Dijital çağda eğitim: Olanaklar ve uygulamalar üzerine bir analiz [Education in digital age: An analysis on opportunities and applications]. Süleyman Demirel Üniversitesi Iktisadi ve İari Bilimler Fakültesi Dergisi, 22(Özel Sayı), $1741-1759$

Patton, M. Q. (2005). Qualitative Research. New York: John Wiley \& Sons, Ltd.

Paudel, P. (2021). Online education: Benefits, challenges and strategies during and after COVID-19 in higher education. International Journal on Studies in Education (IJonSE), 3(2), 70-85. https://doi.org/10.46328/ijonse.32

Roth, B. (2008). The Importance of Parental Encouragement and Support. Retrieved from http://ezinearticles.com/?TheImportance-of-Parental-Encouragement-andSupport\&id=1622042

Sağer, T., Eden, A., \& Şa Ilıel, O.(2014). Müzik eğitiminde uzaktan eğitim ve orkestra uygulamaları [Distance learning in music education and orchestral applications]. Inönü Üniversitesi Sanat ve Tasarım Dergisi, 4(9), 69-79.

Sağer, T., Özkişi, G.Z., \& Yüceer, E.M. (2020). COVID-19 pandemi sürecinin müzik dinleme ve icra pratiklerine etkileri: yıldız teknik üniversitesi lisans öğrencileri örneği [The effects of COVID-19 pandemıc perıod on lıstenıng to and performıng musıc: yıldız technıcal unıversıty undergraduate students sample]. Akdeniz Üniversitesi Uluslararası Müzik ve Sahne Sanatları Dergisi, 4, 1-17. 
Sakarya, G. \& Zahal O. (2020). COVID-19 pandemi sürecinde uzaktan keman eğitimine ilişkin öğrenci görüşleri[The Student Opinions on Distant Violin Education During COVID-19 Epidemic]. Turkish Studies, 15(6), 795-817. https://dx.doi.org/10.7827/TurkishStudies.44504

Sandhu, P. \& Wolf, M. (2020). The impact of COVID-19 on the undergraduate medical curriculum, Medical Education Online, 25:1, 1764740, DOI: 10.1080/10872981.2020.1764740

Subaşı, M.,\& Okumuş, K. (2017). Bir araştırma yöntemi olarak durum çalışması [Case study as a research method]. Atatürk Üniversitesi Sosyal Bilimler Enstitüsü Dergisi, 21(2), 419-426.

Tartavulea, C.V., Albu, C.N., Albu, N, Dieaconescu, R.I. \& Petre, S. (2020). Online teaching practices and the effectiveness of the educational process in the wake of the COVID-19 pandemic. Amfiteatru Economic, 22(55), 920-936.

Tümen Akyıldız, S. (2020). College students' views on the pandemic distance education: A focus group discussion. International Journal of Technology in Education and Science (IJTES), 4(4), 322-334.

Yamamoto, G.T. \& Altun, D. (2020). Coronavirüs ve çevrimiçi (online) eğitimin önlenemeyen yükselişi[The Coronavirus and the Rising of Online Education]. Üniversite Araştırmaları Dergisi, 3(1), 25-34. http://doi.org/10.26701/uad.711110

Yıldırım, A. \& Şimşek, H. (2016). Sosyal bilimlerde nitel araştırma yöntemleri [Qualitative research methods in the social sciences]. Ankara: Seçkin Yayıncılık.

Yungul, O. (2018). Müzik eğitiminde web tabanlı uzaktan eğitim[WEB based distance learning in music education]. Uluslararası Türkçe Edebiyat Kültür Eğitim Dergisi, 7(2), 1333-1348. http://doi.org/10.7884/teke.4227 